\title{
Representasi Kulit Putih Perempuan dalam Iklan MS Glow
}

\author{
Ikhwanul Muslimin Abdullah \\ Program Studi Ilmu Komunikasi, Universitas Muhammadiyah Yogyakarta, Indonesia \\ Ikhwanul.m.isip19@mail.umy.ac.id \\ Hanan Widiasmara \\ Program Studi Ilmu Komunikasi, Universitas Muhammadiyah Yogyakarta, Indonesia \\ hanan.w.isip19@mail.umy.ac.id \\ Muhammad Syarifudin Fajirul Ulum \\ Program Studi Ilmu Komunikasi, Universitas Muhammadiyah Yogyakarta, Indonesia \\ m.syarifudin.isip19@mail.umy.ac.id \\ Diserahkan: 14 Juni 2021; Direvisi: 28 Juni 2021; Diterima: 29 Juni 2021
}

\begin{abstract}
This study was conducted to determine the representation of white women in MS Glow advertisements by looking at the beauty standards of Indonesian women. The research conduct in semiotic method. White women's skin is an interesting thing to study about someone's view of women's beauty and women's beauty standards according to society and MS Glow advertisements. This study uses the theory of representation, body beauty and advertising through semiotic methods. It was found that MS Glow advertisements represent white, clean and smooth skin is the ideal skin and is the dream of every woman.
\end{abstract}

Keywords: Facial Skin; MS Glow; Women; Representation

\section{Abstrak}

Penelitian ini dilakukan untuk mengetahui representasi kulit putih perempuan dalam iklan MS Glow dengan melihat standar kecantikan perempuan Indonesia. Metode penelitian yang dipilih adalah semiotika. Kulit putih perempuan merupakan hal yang menarik untuk diteliti mengenai pandangan seseorang terhadap kecantikan perempuan dan standar kecantikan perempuan menurut masyarakat dan iklan MS Glow. Penelitian ini menggunakan teori representasi, tubuh kecantikan dan iklan melalui metode semiotika ditemukan bahwa iklan MS Glow merepresentasikan kulit putih, bersih dan mulus adalah kulit ideal dan menjadi dambaan setiap perempuan.

Kata Kunci: Kulit Wajah; MS Glow; Perempuan; Representasi 


\section{PENDAHULUAN}

Semua perempuan ingin mempunyai penampilan yang menarik seperti kulit putih, cerah dan bersih sehingga mereka banyak menghabiskan waktu untuk merawat kulitnya terutama pada kulit wajah. Kulit wajah merupakan organ yang sangat sensitif dan memerlukan perawatan yang khusus. Perawatan untuk menjaga kulit wajah dapat dilakukan dari dalam maupun dari luar tubuh. Salah satu contoh perawatan dari dalam tubuh adalah dengan mengkonsumsi makanan-makanan yang banyak mengandung vitamin serta mengkonsumsi suplemen untuk kulit. Kecantikan merupakan benteng pertahanan perempuan yang sekarang diserang industri kecantikan. Dalam arus globalisasi sekarang ini, ukuran ideal menurut nilainilai lokal terpinggirkan oleh pencitraan yang dilakukan secara masif oleh iklan-iklan komersial. Salah satunya adalah iklan MS Glow.

Penelitian ini akan membahas tentang representasi kulit putih perempuan dalam iklan MS Glow yang dikatakan bahwa di dalam iklan tersebut seorang model perempuan yaitu Sarwendah mengatakan bahwa MS Glow dapat mengatasi berbagai masalah wajah kulit, memutihkan kulit menjadi normal, bersifat alami dan aman, terbukti dan memberikan efek kulit wajah tampak putih alami dan kembali seperti bayi. Hal tersebut cukup bertentangan dengan warna kulit orang indonesia yang berada di wilayah beriklim tropis.

Representasi warna kulit perempuan dalam iklan telah menjadi obyek penelitian dalam beberapa penelitian terdahulu. Salah satunya adalah Penelitian oleh (Sari, 2015) menemukan bahwa iklan Pond's White Beauty dengan bintang Gita Gutawa yang bertema "Cantik Putih Merona seperti Korea" menciptakan konflik budaya dalam hal makna kecantikan bagi perempuan Indonesia. Hal ini dibuktikan dengan melakukan analisis semiotik pada iklan Pond'es White Beauty dengan temuan di dalamnya yang mana stereotip perempuan cantik merupakan perempuan yang berkulit putih seperti perempuan Korea. Hal ini bertolak belakang dengan ras yang dimiliki orang Indonesia sendiri, artinya genetik menjadi tolak ukur yang tidak dapat disamakan dalam sebuah iklan (Sari, 2015).

Kemudian Penelitian lainnya yang di lakukan oleh (Aisyiyah, 2013) menemukan bahwa standar kecantikan yang ingin disampaikan oleh pihak Dove adalah perempuan yang cantik adalah perempuan yang memiliki rasa percaya diri, bersyukur atas apa adanya dirinya, menjaga kecantikan alami yang telah diberikan oleh Tuhan, dan tidak berusaha untuk menjadi orang lain. Kampanye dengan tema Real Beauty Real Friends ini, Dove memperluas standar perempuan yang cantik adalah perempuan yang menghargai nilai pertemanan, yang mempunyai rasa solidaritas tinggi dalam pertemanan, serta saling mendukung dengan sesama teman. (Aisyiyah, 2013)

Penelitian lainnya oleh (Mondong, 2011) menyimpulkan terjadinya pergeseran makna cantik antara wanita abad ke-18 dengan wanita cantik abad ke-21 dewasa ini. Wanita cantik abad Abad ke-18 Indonesia, meski sangat dipengaruhi oleh definisi cantik ala Wanita Eropa tapi masih bisa mempertahankan warna kulitnya yang melayu; kuning/ sawo matang seperti kebanyakan kulit masyarakat Indonesia atau rambutnya yang berombak. Tetapi kini di Indonesia terdapat pergeseran lagi, kulitnya harus putih, rambutnya harus panjang lurus mengkilat tidak lagi berombak. Dan oleh karena itu, warga negara Indonesia yang mayoritas warna kulitnya kuning/sawo matang menjadi sasaran empuk produk-produk pemutih. Para wanita di bombardir oleh iklan-iklan yang mendefinsisikan cantik dan putih ala Eropa/barat. (Mondong, 2011)

Perbedaan penelitian kami dengan penelitian terdahulu yakni terletak pada penelitian tentang perempuan berkulit putih yang memakai produk MS Glow yang berada di Indonesia. Sedangkan penelitian terdahulu yang lakukan oleh (Sari, 2015) menemukan bahwa iklan Pond's White Beauty dengan bintang Gita Gutawa yang bertema "Cantik Putih Merona seperti Korea" mengatakan adanya perbedaan genetik antara orang Korea dan orang Indonesia yang dimana orang Korea lebih cenderung mempunyai Stereotip yang didalamnya merupakan perempuan berkulit putih. Di sisi lain, penelitian 
terdahulu yang di lakukan oleh (Aisyiyah, 2013) mengatakan perempuan yang memiliki rasa percaya diri, dan bersyukur atas apa adanya dirinya, menjaga kecantikan alami yang telah diberikan oleh Tuhan.

\section{KAJIAN PUSTAKA}

\section{REPRESENTAS}

Christopher Prendergast mengatakan beberapa definisi untuk istilah 'representasi'. Yang pertama adalah arti representasi sebagai hadir kembali, untuk membuat presentasi lagi, ada dua cara yang saling terkait yaitu, spasial dan temporal. Dimaksudkan untuk mengutip, atau 'kutipan', sebuah kehadiran, yang mengacu pada sesuatu yang tidak ada, tetapi diasumsikan otentik dan berpotensi hadir (suara otentik, dan sebagainya). Ini adalah representasi sebagai Darstellung, gagasan membuat atau menghadirkan kehadiran. Dalam mode ini, representasi tertentu dapat memiliki kapasitas untuk membuat terlihat, di sini dan sekarang, sesuatu yang dulu (atau mungkin telah) hadir di sini dan saat ini- ia mengakomodasi kedua ruang (sudah dikirim sebelumnya) dan waktu (saat ini).

Arti kedua yang ditawarkan Prendergast adalah mendelegasikan kehadiran, atau Vertretung: penggantian sesuatu untuk sesuatu atau orang lain. Hal ini paling sering terlihat dalam bahasa dan politik. Dalam bahasa, sebuah kata membuat hal yang konkret, atau ide, hadir dalam percakapan atau tulisan. Sebagai contoh, saya mengatakan 'gajah', dan meskipun tidak ada gajah di ruangan itu, konsep gajah diubah, atau dibawa ke kesadaran - dibiarkan menggantikan hewan itu. Dalam politik, seseorang dinominasikan untuk mewakili, dan berbicara. Mendelegasikan suara politik kepada pengganti di pemerintahan, di serikat pekerja atau di pengadilan. Baik dalam bahasa dan politik, pengertian representasi ini memungkinkan sebuah istilah, citra, atau agen untuk menggantikan objek, ide, atau orang yang tidak ada (Jackson, 2010).

Representasi merupakan sebuah konsep atau proses yang mengkaji tentang simbol atau tanda. Yaitu mewujudkan sebuah konsep atau ide dalam bentuk simbolis. yang dapat di artikan dan di maknai oleh seseorang. Secara garis besar yang di maksud dengan di maknai oleh seseorang adalah 'praktik representasi' Artinya harus memasukkan domain atau tanda tersebut ke dalam praktek. Hal tersebut dapat menghubungkan suatu makna dan bahasa budaya. "Represeníaíion ini berarti menggunakan bahasa untuk mengatakan sesuatu untuk merepresentasikan kepada orang lain supaya mendapatakan sebuah pertukaran informasi. penggunaan gambar juga dapat mewakili sesuatu makna. Tetapi dalam representasi hal ini jarang di gunakan, di karenakan proses tersebut butuh imajinasi yang tinggi agar gambar tersebut dapat dimaknai dengan benar (Hall, 2012).

\section{TUBUH, KECANTIKAN DAN IKLAN}

David Theo Goldberg telah mengatakan bahwa, nilai klasik tubuh kecantikan dibangkitkan dan disamakan dengan nilai ekonomi. Orang miskin didefinisikan sebagai orang yang tidak memiliki karakteristik rasial dari "kulit putih, rambut lurus, rahang bergelombang, bentuk tengkorak dan ukuran, proporsi tubuh yang tersusun baik, dan sebagainya. bahkan paling rasial masyarakat saat ini mengikuti perkembangan zaman, yang dimana warna kulit tubuh dijadikan salah satu mode referensi tren kulturasi yang disertakan dari segi mode pakaian, sikap, gaya berjalan, gaya rambut, ucapan, dan hubungan mereka (Frith \& Gates, 2011).

Menurut Institute of Practitioners in Advertising (IPA) menyebutkan bahwa periklanan merupakan mengupayakan suatu pesan penjualan yang supersuasif mungkin kepada calon pembeli yang paling tepat atas suatu produk berupa barang atau jasa tertentu dengan biaya yang semurah-murahnya (Muktaf, 2015). Sandra Moriarty dan kawan-kawan mendefinisikan bahwa periklanan adalah sebagai bentuk komunikasi berbayar yang menggunakan media massa dan juga media interaktif untuk menjangkau audiensi yang 
luas dalam rangka menghubungkan sponsor yang jelas dengan membeli (audiensi sasaran) dan memberikan informasi tentang produk (barang,jasa,dan gagasan) (Muktaf, 2015).

Iklan juga dapat diartikan sebagai Komunikasi pemasaran terpadu yang mana proses ini, upaya untuk menjadikan seluruh kegiatan pemasaran dan promosi perusahaan dapat menghasilkan citra atau image yang bersifat satu dan konsisten bagi konsumen. Upaya ini menuntut agar setiap pesan yang keluar harus berasal dari sumber yang sama schingga segala informasi yang diumumkan perusahaan memiliki kesamaan tema serta positioning yang sama di mata konsumen (Morissan, 2010).

\section{METODE PENELITIAN}

Dalam penelitian ini, penelitian ini mencoba menanggapi pengembangan masalah yang memberikan respons terhadap pengembangan masalah ini yang di sebut semiotike. Sausessure pun menolak bahwa asumsi bahwa bawasannya bahasa mencerminkan fakta dan menunjukkan bahwa revolusi bekerja pada sistemnya sendiri. Sistem ini membangun poin dalam dialek, itu berarti bahwa, itu alami atau istimewa. Lalu Dia menyebutnya juga jalan ini ke semiologi, yang berarti menganalisis tanda-tanda, tetapi kita menggunakan lebih banyak kondisi dengan cara ini. Ada dua istilah atau kata-kata, Tetapi tidak ada hubungan dengan suara. Bahasa ini biasanya sama, dan perbedaan membawa ide, yang menunjukkan berbagai pendapat beberapa suara (Laughey, 2007)

Oleh karena itu, untuk memvariasikan kemewahan dalam teks. Munculah suatu tanda atau gejala termasuk dua bagian simbol atau sebuah pemberitahuan dan merek. Simbol dapat dipahami sebagai perintah atau proses fisik. Simbol-simbol dapat berbunyi, gambar, alfabet, dengan kata lain simbol tersebut mempunyai berupa ide dan makna (Harttley, 2003). Saussure kemudian memperkenalkan Langue( Bahasa) dan Parole (Bentuk konkret dari langue). Langue adalah desain dan ekspresi bahasa di tingkat sosial sedangkan parole adalah ekspresi bahasa di tingkat individu. Agar lebih mudah dipahami, ekspresi wajah merupakan salah satu cara orang berbicara dengan cara yang formal. sedangkan bisa kita sebut dengan bahasa dan struktur dari bahasa umum. Oleh karena itu, parole merupakan bentuk dari langue yang berkaitan dengan bahasa.

Ide Saussure dikembangkan oleh Roland Barthes. Barthes menyampaikan kontribusi penting lainnya untuk memahami peran media dalam mentranskripsi gagasan. Barthes mengacu pada karya Saussure dan teorinya tentang semiotika, yang telah memasuki dunia media dan penelitian sosial pada 1960-an. Ia beranggapan bahwa pentingnya media dalam menyiarkan gagasan atau pandangan dunia didasarkan pada kemampuan mereka untuk menyusun tanda dan gambaran dengan cara tertentu. Budaya lebih dari apa yang tampak secara lahiriah.

Secara khusus, mereka melihat bahwa melalui proses pemaknaan, media membuat makna dan perspektif tertentu tampak alami dan sensitif dalam masyarakat (Williams, 2003). Gagasan Barthes yang berperan penting dalam penafsiran tanda adalah tentang mitos. Bahkan, ia tetap melanjutkan asumsi Saussure tentang hubungan antara bahasa dan makna. satu atau antara tanda dan karakter. Semiotika yang dikonstruksikan oleh Saussure cenderung menunjukkan makna sebagaimana makna tanda.

Oleh karena itu, pada awal kemunculannya tradisi semiotik cenderung menunjuk pada makna yang disebut juga semiotika.Barthes lebih jauh mengeksplorasi gagasan makna denotatif atau makna pada tingkat primer (makna primer). Menurut Barthes, ada makna lain yang benar-benar bermain pada level yang lebih dalam, yaitu level konotasi atau makna sekunder (secondary makna). Saussure dikembangkan oleh Barthes, yang mendobrak praktik tanda pada tingkat konotasi tanda. Konotasi bagi Barthes sebenarnya menunjukkan sesuatu yang ia nyatakan sebagai mitos, dan bahwa mitos memiliki konotasi bagi ideologi tertentu.

Dengan demikian, pemikiran Saussure dikembangkan oleh Barthes dengan membongkar praktik pertandaan di tingkat konotasi tanda. Konotasi bagi Barthes justru mendenotasikan sesuatu hal yang ia 
nyatakan sebagai mitos, dan mitos ini mempunyai konotasi terhadap ideologi tertentu. Secara operasional, penelitian ini menerapkan semiotika dengan mengkaji karakter-karakter yang terdapat pada iklan MS Glow. Iklan MS Glow yang diperiksa ditempatkan sebagai teks yang terdiri dari karakter yang berbeda. Dan adegan di iklan MS Glow. Dalam Penelitian Pada tahap hasil, peneliti akan menyajikan makna denotatif dan konotatif, dilanjutkan dengan diskusi di mana intertekstualitas hasil penelitian dianalisis dengan berbagai teori yang relevan

\section{HASIL DAN PEMBAHASAN}

HASIL

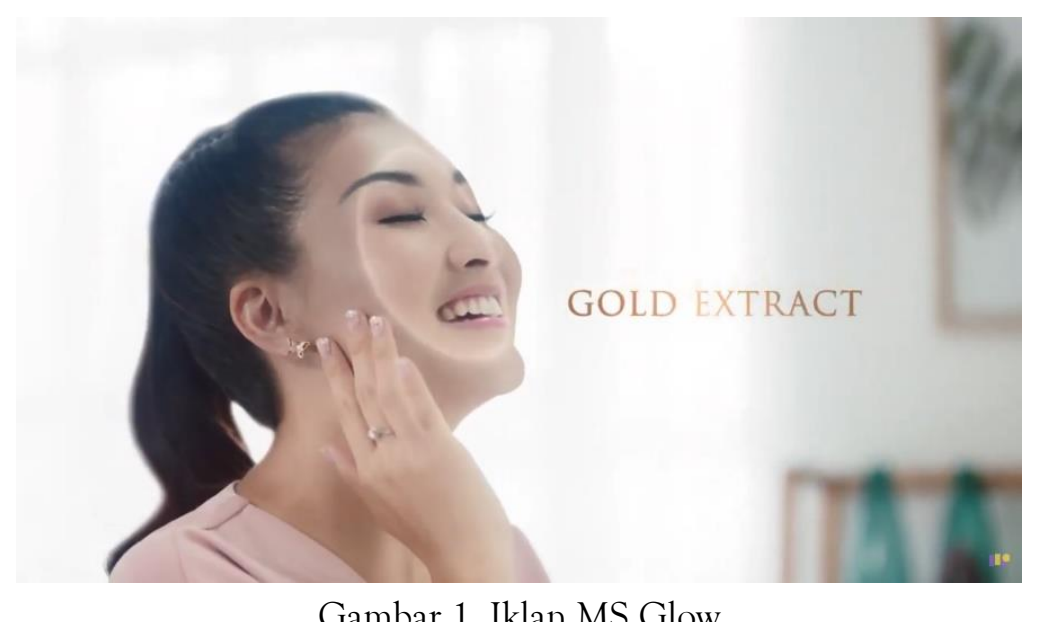

Makna denotasi: Penanda iklan ini adalah seorang perempuan sedang menggunakan produk pemutih dari MS Glow yang langsung terlihat cerah dan bersih, ditambah dengan adanya narasi yang berbunyi "Efektif menghilangkan bintik hitam di wajah serta mencerahkan kulit, Aku bebas dari rasa khawatir". Dari pernyataan tersebut membuktikan bahwa mempunyai kulit putih dan bersih adalah suatu kebahagiaan bagi wanita, hal ini yang kemudian membuat standar kecantikan di Indonesia adalah orang yang mempunyai kulit cerah dan bersih.

Makna Konotasi: Kulit cerah adalah jenis kulit yang paling bagus. Banyak perempuan yang ingin memiliki kulit cerah sehingga kulit cerah menjadi standar kulit ideal di Indonesia, seperti yang tertera pada Gambar 1 yakni sumber kebahagiaan setiap wanita adalah memiliki kulit yang cerah.

Mitos: Dengan menggunakan MS Glow dapat terlihat cantik sepanjang hari. Namun mempunyai wajah yang cantik dan bersih bukan hanya memakai produk MS glow, tetapi juga banyak cara untuk mempunyai wajah yang cantik dan bersih yaitu dengan menggunnakan produk lain selain MS Glow yang dapat membuat wajah menjadi cantik dan bersih. Kulit cerah yang dihasilkan dari penggunaan MS Glow dimitoskan sebagai kulit ideal. 


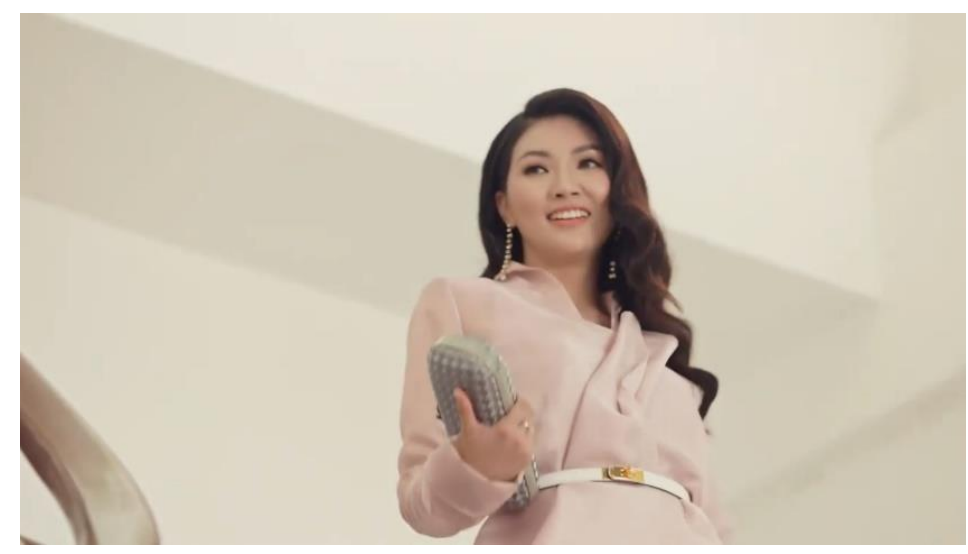

Gambar 2. Iklan MS Glow

Makna Denotasi: Petanda dalam iklan ini adalah seorang perempuan yang memiliki tubuh kurus, rambut lurus dan kulit putih sedang menuruni tangga dengan muka bahagia dan percaya diri setelah memakai produk pemutih MS Glow. Dengan narasi yang berbunyi "Dan tetap cantik sepanjang hari”.

Makna Konotasi: Perempyan berkulit putih adalah wanita yang bahagia. Perempuan mudah merasa insecure terutama pada keindahan fisik mereka.

Mitos: Pada iklan di atas bahwa mempunyai tubuh kurus, rambut lurus, dan kulit putih dapat menambah percaya diri pada seseorang, dan selalu dipandang sebagai standar cantik.

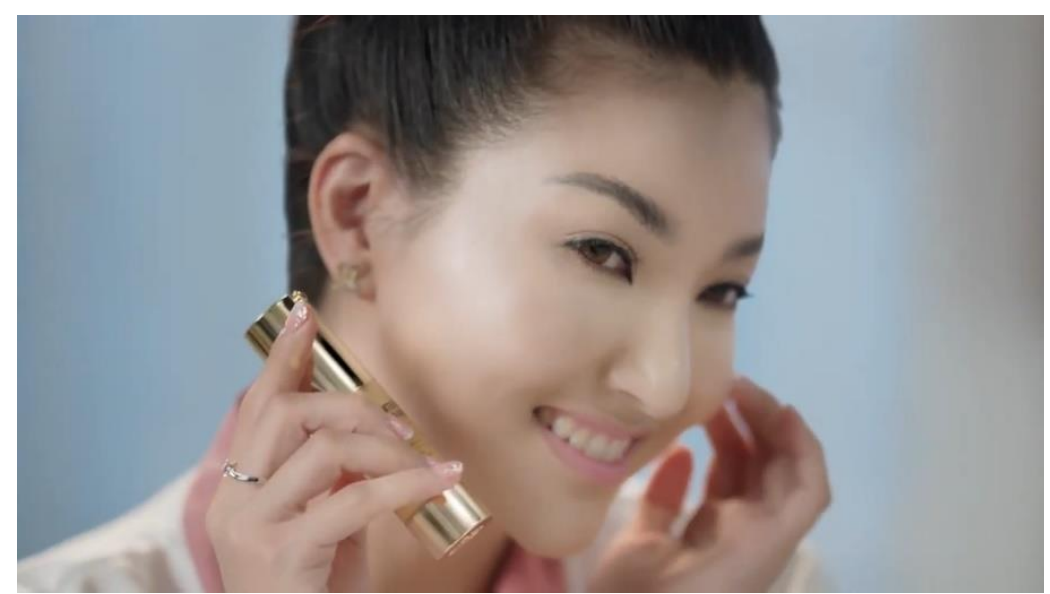

Gambar 3. Iklan MS Glow

Makna Denotasi: Petanda pada gambar ini adalah seorang perempuan yang setelah menggunakan produk MS Glow menjadi terhidar dari kulit keriput dan tampak awet muda. Tanda yang dihasilkan yakni wajah menjadi bersih dan glowing.

Makna Konotasi: Perempuan yang memiliki wajah keriput dan tua dianggap tidak cantik. Banyak perempuan yang takut akan penuaan karena mereka menganggap bahwa wajah keriput membuat penampilan mereka tidak menarik.

Mitos: Perempuan yang menggunakan produk MS Glow terhindar dari kulit keriput dan tampak awet muda. Ini menjadi mitos fisik perempuan yang ideal. Perempuan di Indonesia maupun di luar negeri mempunyai cara dan treatment sendiri-sendiri untuk terhindar dari kulit keriput dan tampak awet muda. Ini dilakukan dengan selalu menjaga makanan dan minum yang sehat seperti memakan sayuran, buahan, dan minum air putih setiap hari. 


\section{PEMBAHASAN}

Media dan industri kecantikan telah bekerja sama untuk mengubah persepsi tentang kecantikan seorang wanita yaitu kulit putih, bersih dan mulus sehingga wanita yang tidak memiliki itu semua dianggap tidak ideal dan tidak memenuhi standar, menurut (Piliang, 2003) logikanya, mustahil sebuah perusahaan mau mengeluarkan dana puluhan, sampai ratusan miliar rupiah untuk iklan, bila sebuah iklan tidak bisa merubah persepsi dan hasrat membeli pada masyarakat.

Perempuan yang memenuhi standar kecantikan cenderung diperlakukan "istimewa" dan lebih cepat diterima oleh lingkungan sekitar, seperti yang dikatakan oleh (Hurlock, 1991). Apabila seseorang tersebut menarik maka biasanya akan dia diperlakukan secara lebih baik atau lebih dihormati. Sebaliknya bila seseorang mempunyai penampilan kurang menarik maka dia akan diperlakukan biasa-biasa saja bahkan cenderung diperlakukan secara kurang simpatik. Hal tersebut mengakibatkan insekuritas bagi kaum perempuan yang tidak memenuhi standar kecantikan, hilangnya kepercayaan diri akibat tidak menarik, (Santrock, 2003) mengungkapkan kepercayaan diri dipengaruhi oleh beberapa faktor, yaitu; penampilan fisik, konsep diri, hubungan dengan orang tua dan hubungan dengan teman sebaya.

Tabel 1. Oposisi Biner Relasi Perempuan cantik dan Perempuan tidak cantik dalam iklan.

\begin{tabular}{|c|c|}
\hline Perempuan cantik & Perempuan tidak canik \\
\hline Kulit putih & Kulit hitam \\
\hline Tubuh tinggi & Tubuh pendek \\
\hline Badan Kurus & Badan gemuk \\
\hline Rambut panjang & Rambut pendek \\
\hline
\end{tabular}

Representasi yang dibuat oleh pelaku media seringkali membuat perempuan tidak merasa puas akan penampilan mereka, ada beberapa penyebab salah satunya adalah faktor eksternal yakni mereka sering menerima perkataan dari teman, kerabat bahkan keluarga tentang bentuk dan jenis fisik yang mereka miliki tidak memenuhi standar kecantikan. Hal ini yang membuat perempuan lebih mudah merasa insecure atau tidak percaya diri

Perempuan yang menarik memiliki benefit terutama di dunia kerja, ini karena orang yang penampilan fisiknya menarik cenderung dianggap memiliki kepribadian yang menarik pula, sepeti tenang, penuh kehangatan, penuh perhatian, pandai bersosialisasi, tidak memiliki sifat ketergantungan, dan hasil pekerjaan mereka umumnya dianggap baik pula. Percaya diri juga merupakan salah satu faktor yang dapat memberikan citra positif pegawai di depan rekan kerja (Rickieno, 2008).

Banyak perusahaan yang menetapkan peraturan ini sebagai syarat diterimahnya pekerjaan di perusahaan tersebut, akibatnya banyak hak-hak penyandang disabilitas dan perempuan yang dianggap tidak menarik sulit dalam mencari pekerjaan. Perempuan yang dianggap menarik juga seringkali dieksploitasi oleh pelaku media untuk mencari views dan keuntungan mereka semata. Oleh karena itu, kekaguman-kekaguman terhadap perempuan, terkadang tanpa disadari terlihat sangat diskriminatif ketika perempuan hanya dijadikan simbol dalam seni-seni komersial, yang ditayangkan melalui karyakarya seni kreatif seperti iklan, sehingga menjadi konsumsi masyarakat dalam berbagai media masa dan posisi perempuan sangat potensial untuk dieksploitasi (Thadi, 2018). 


\section{KESIMPULAN}

Dari hasil penelitian, dapat disimpulkan bahwa iklan MS Glow sangat berpengaruh pada persepsi khalayak bahwa kulit putih, bersih dan mulus adalah kulit ideal dan menjadi dambaan setiap wanita sehingga wanita yang tidak memiliki kulit putih, bersih dan mulus dianggap tidak menarik. Maka, dalam iklan MS Glow merepresentasikan kulit putih seorang wanita. Dimana pada iklan MS Glow dapat disimpulkan bahwa, pertama dalam iklan MS Glow pada Gambar 1 digambarkan seorang perempuan memakai produk dari MS Glow kemudian perempuan itu menjadi putih, bersih dan mulus tak lama wanita itu langsung percaya diri dan bebas dari rasa khawatir sehingga wanita yang memiliki kulit putih, bersih dan mulus pasti memiliki kepercayaan diri yang tinggi.

Kedua, dalam iklan MS Glow pada Gambar 2 terlihat seorang perempuan yang memiliki rambut lurus bergelombang dan badan langsing bisa meningkatkan kepercayaan diri seorang perempuan. Ketiga, pada iklan MS Glow Gambar 3 terlihat seorang perempuan yang memakai produk MS Glow terhindar dari kulit keriput dan menjaga kulit tetap mulus. Kulit yang mengalami penuaan dianggap sudah tidak menarik lagi, kulit wanita harus tetap mulus meski sudah berumur tua.

Jenis dan bentuk fisik perempuan berkaitan dengan kehidupan sosial dan pekerjaan, perempuan yang menarik cenderung lebih disegani banyak orang ketimbang wanita yang kurang menarik, akibatnya perempuan menarik seperti menjadi "objek" yang hanya dinikmati keindahannya saja padahal bentuk dan jenis fisik tidak bisa dijadikan patokan kualitas seorang wanita, kebanyakan orang melihat dari luarnya saja dan lupa akan kecantikan dari dalam. Begitu juga dengan pekerjaan banyak perusahaan yang mengharuskan para calon karyawan dan karyawannya berpenampilan menarik, hal ini menjadi beban tersendiri bagi wanita yang kurang menarik dan penyandang disabilitas. Perempuan menarik juga banyak dieksploitasi para pelaku media semata-mata hanya untuk meningkatkan rating, laba dan views.

\section{PERSANTUNAN}

Terima kasih kepada Dr. Fajar Junaedi yang telah membimbing kami dalam proses penelitian ini. Penelitian ini ditulis untuk memenuhi tugas mata kuliah Kajian Kritis Iklan pada Program Studi Ilmu Komunikasi UMY dalam satu semester genap tahun akademik 2020/2021 yang telah menghasilkan output berupa artikel ini.

\section{REFERENSI}

Aisyiyah, R. N. (2013). Kecantikan Dalam Iklan: Gambaran Kecatikan Dalam Iklan Sabun Dove Di Televisi. Ilmu Komunikasi, 1(4), 63-80.

Frith, S., \& Gates, H. L. (2011). A Dictionary of cultural and critical theory. Choice Reviews Online (Vol. 48, Issue 09). https://doi.org/10.5860/choice.48-4853

Hall, S. (2012). Cultural Representation. The Encyclopedia of Applied Linguistics. https://doi.org/10.1002/9781405198431.wbeal0300

Harttley, J. (2003). A Short History of Cultural Studies. SAGE Publications Ltd. https://doi.org/10.4135/9781446216934

Hurlock, B. (1991). Psikologi Perkembangan: Suatu Pendekatan Sepanjang Rentang Kehidupan (R. M. Sijabat. Erlangga.

Jackson, F. (2010). Language, Names, and Information. Blackwell Publishing. https://doi.org/10.1002/9781444325362.ch2

Laughey, D. (2007). Key Themes in Media Theory (1st ed.).

Mondong, T. (2011). Presentable, Acceptable, Inovasi, 8, 113-130.

Morissan, M. A. (2010). Periklanan Komunikasi Pemasaran Terpadu (1st ed.). PRENADAMEDIA GROUP. 
Muktaf, Z. M. (2015). Periklanan Sebuah Pendekatan Praktis. Buku Litera: Yogyakarta.

Piliang, Y. A. (2003). Hipersemiotika Tafsir Cultural Studies Atas Matinya Makna. Jalasutra: Yogyakarta.

Rickieno, R. (2008). Menjadi Karyawan Idaman dalam 4 Minggu. Mutiara Benua.

Santrock, J. W. (2003). Adolescence: Perkembangan Remaja. Erlangga: Jakarta.

Sari, W. P. (2015). Konflik Budaya Dalam Konstruksi Kecantikan Wanita Indonesia (Analisis Semiotika

Dan Marxist Iklan Pond's White Beauty Versi Gita Gutawa). Jurnal Komunikasi, 7(2), 198-206. https://journal.untar.ac.id/index.php/komunikasi/article/view/18

Thadi, R. (2018). Citra Perempuan dalam Media. Jurnal Ilmiah Syi'ar. 14(1), 27-38. https://doi.org/http://dx.doi.org/10.29300/syr.v14i1.1423

Williams, K. (2003). Understanding Media Theory. Arnold 